\title{
THE EARLY HISTORY OF THE PSALTER
}

\author{
Roger T. Beckwith
}

\section{Summary}

The Psalms are full of references to music, Jerusalem and the sanctuary. Chronicles, Ezra and Nehemiah say they were being performed there by the Levites, and the titles (which have a marked community of ideas and language with those books, though without dependence) endorse this. The division into five books pre-dates the LXX version, but there are many indications, in the text and titles, of a still earlier division into three. The meaning of the musical directions and other technical terms in the titles had been forgotten, in Semitic circles as well as Hellenistic, before the LXX version was made. Since, after the Exile, the Psalms were being performed continuously, this suggests that the titles are even pre-exilic. The final component of the titles has its own history. The eccentric Psalms MSS from Qumran are probably liturgical adaptations.

The article is followed by a tabular analysis of the psalm-titles.

\section{Introduction}

The external form of the Book of Psalms is unique in the Bible. It consists of 150 separate items (occasionally counted as slightly fewer, where pairs of psalms are run together), divided into five books, the last psalm of each book ending with a doxology which belongs as much to the book as it does to the psalm, if not more. The whole of the last psalm serves as the fifth doxology. 116 of the psalms (and more still in the Greek) are preceded by a title.

The psalms are all religious in character and poetical in form. In roughly a third of them, drawn from various parts of the Psalter, the predominant sentiments are of praise and thanksgiving, in another third petition, and in the remaining third instruction, meditation, confession of faith or confession 
of sin. In few of them, however, are the sentiments exclusively of one kind: rather, the psalmist moves from one sort of devotion to another. The book is known in Hebrew by the name těhillîm ('praises'), a term which frequently occurs in the text of the psalms, as does tĕphillôt ('prayers'), also. Various technical names for different types of psalm are found in the psalmtitles: mizmōr ('melody'), šîr ('song'), maskîl ('contemplative poem'), and miktām (perhaps 'psalm of protection'). ${ }^{1}$ The distinctions between these are very imperfectly understood: even with a word like maskîl, which seems to have a plain rootderivation, it is hard to see why it has been applied to particular psalms and not others. The Greek name for the book is psalmoi, songs of praise, though Philo normally calls it humnoi, which has a very similar meaning.

The psalms are not only poetical but musical. The words 'sing' and 'song' occur very frequently in psalms of all five books. Musical instruments are mentioned in the texts of fifteen psalms, which again are distributed throughout the five books. Musical directions are given in the titles of many psalms, especially in the first three books: often the directions simply say 'for the chief musician/choirmaster' (měnatșēah), but sometimes they are considerably fuller, though difficult to understand.

These musical directions clearly envisage some sort of public performance of the 55 psalms which carry them (and not necessarily of those psalms alone). Since the religious focus of the Psalms is Jerusalem and its sanctuary (the text of the Psalms mentions Jerusalem, Zion, the tabernacle, the temple, the sanctuary, the ark, the altar, the city or house or dwellingplace of God about 118 times), the titles can hardly mean that the public performance of the psalms was to take place anywhere but there, and this is confirmed by the explicit

\footnotetext{
${ }^{1}$ This suggestion is made by J.A. Motyer in D.A. Carson et al. (eds.), New Bible Commentary (Leicester: IVP, 1994) 486, in his helpful brief introduction to the Psalter. A good fuller introduction is to be found in P.C. Craigie, Psalms 1-50 (Word Biblical Commentary; Waco: Word Books, 1986). The writer of this article is grateful to Mr. Motyer for reading it through in manuscript, and for making many wise suggestions and corrections.
} 
statements of the books of Chronicles, Ezra and Nehemiah about the 'service of song' in the house of the Lord at Jerusalem, to which certain families of Levites were appointed.

\section{The Evidence of Chronicles, Ezra and Nehemiah}

The Books of Chronicles were probably written about $400 \mathrm{BC}$, or not much later, and the books of Ezra and Nehemiah may well be somewhat older. Considerable doubts have been raised about the historicity of Chronicles, but Ezra and Nehemiah are generally regarded as substantially historical; and even if Chronicles were unhistorical in its narratives, it could still be used as reliable evidence of what was believed by the Chronicler, four centuries before Christ. Certainly the Chronicler's interests were very different from those of the writers who drew up the parallel narrative in Samuel and Kings, but to assume that he invented his material, and did not find much of it in the prophetic histories to which he refers as his sources, is arbitrary. Now that so much doubt has been thrown on the late date formerly attributed to the 'priestly' material in the Pentateuch, the parallel material in Chronicles, assigned to the period of the monarchy, ceases to be selfevidently anachronistic.

About ten passages are relevant to our subject. Four of them concern the reign of David. In 1 Chronicles 15:16-28 we read of the bringing of the ark to Jerusalem by David. At his command, its journey is accompanied by the Levitical singers, led by Heman, Asaph and Ethan, with cymbals, while others play psalteries (or lutes) set to Alamoth and harps set to the Sheminith-possibly settings suited to different kinds of voices. The master of the song is Chenaniah, chief of the Levites, who instructs the singers because of his skill.

Going back to 1 Chronicles 6:31-47, in the genealogies, we are told that, after the ark had rest, in the Tabernacle of the tent of meeting, David set the same three over the service of song there, until Solomon had built the Temple; namely Heman, one of the sons of Korah, belonging to the family of Kohath, Asaph, belonging to the family of Gershom, and Ethan, belonging to the family of Merari-their ancestry is this 
time given, showing that they. were representatives of each of the three main families of the tribe of Levi ( $c p$. Nu. 3:1-4:49; 1 Ch. 6:1-30).

The narrative of David's actual appointment of the Levites to this task is given in 1 Chronicles 16:4-42. He appointed them to minister before the ark, to celebrate, thank and praise the Lord: Asaph (now described as the chief) with cymbals, also Heman and Jeduthun (another name for Ethan?) with trumpets and cymbals, and others with psalteries and harps. On that day, we are told, did David first ordain to give thanks unto the Lord, by the hand of Asaph and his brethren, in words which we know as parts of Psalms 105, 96 and 106 (anonymous psalms, all from Book IV of the Psalter). And he left them there, to minister before the ark continually, as every day's work required.

Finally, in 1 Chronicles 25, when David at the end of his reign is making preparations for the Temple to be built by his son Solomon, he divides the Levitical singers into 24 courses, to minister in turn. In 1 Chronicles 23:5 we have been told that there were 4,000 of them, but in chapter 25 David singles out 288 as specially skilful, led by sons of Asaph, Heman and Jeduthun, and divides them, according to the names of those sons, into 24 courses. Here they are not only described as singing and playing harps, psalteries and cymbals, but as prophesying. Asaph himself is said to prophesy under the supervision of the king, Jeduthun to prophesy in giving thanks and praising the Lord, and Heman is called the king's seer in the words of God. Their sons also are described as prophesying with harps, psalteries and cymbals, which seems to imply that they not only performed inspired psalms but composed them. The prophetic language is repeated and varied, and there seems to be no reason why it should not be given its full weight.

This is what is said about the reign of David. It is easy to understand why the Chronicler should think that the 'sweet psalmist of Israel' was the appropriate person to have instituted all this: but since he was the king, and the one who brought the ark up to Jerusalem, and the one who wished to build the Temple and knew that his son would indeed build it, is 
he not also, historically speaking, the most probable person to have instituted it?

Passing to later reigns, 2 Chronicles 5:12-14 describes Asaph, Heman and Jeduthun, accompanied by their sons and other Levites, with cymbals, psalteries and harps, singing praise and thanks to the Lord at the dedication of Solomon's Temple. 2 Chronicles 20:19 describes the children of the Kohathites and of the Korahites (presumably relatives of Heman) praising the Lord in the Temple in the reign of Jehoshaphat. 2 Chronicles 29:25-30, speaking of Hezekiah's reformation, says that he set the Levites in the house of the Lord with cymbals, psalteries and harps, the instruments of David, according to the commandment of David and his court prophets; that, when the burnt offering began, the song of the Lord began also; and that Hezekiah commanded the Levites to sing praises unto the Lord with the words of David and of Asaph the seer. Then, at Josiah's passover, 2 Chronicles 35:15 says that the singers, the sons of Asaph, were in their place, according to the commandment of David and Asaph and Heman and Jeduthun the king's seer.

Going on to the return from the Exile and the building of the Second Temple, Ezra 3:10-11 says that, when the builders laid the foundation of the Temple, they set the priests in their apparel with trumpets, and the Levites the sons of Asaph with cymbals, to praise the Lord, according to the order of David king of Israel. Also, Nehemiah 11:17 names Mattaniah the son of Asaph, who was the chief to begin the thanksgiving in prayer, and Abda the son of Jeduthun; Nehemiah 11:22 says that Abdi, one of the sons of Asaph, the singers, was the overseer of the Levites at Jerusalem and over the business of the house of God; and Nehemiah 12:45-46 says that the singers were among those who kept the ward of their God, according to the commandment of David and of Solomon his son; for in the days of David and Asaph of old there was a chief of the singers (presumably Chenaniah, cp. 1 Ch. 15:22, 27) and songs of praise and thanksgiving unto God.

This is a remarkable amount of evidence, and we will compare it later with the evidence provided by the Psalms themselves. 


\title{
III. The Five Books
}

The five books of the Psalter are as follows:

\author{
Book I : Psalms 1-41 (in Greek, 1-40) \\ Book II : Psalms 42-72 (in Greek, 41-71) \\ Book III : Psalms 73-89 (in Greek, 72-88) \\ Book IV : Psalms 90-106 (in Greek, 89-105) \\ Book V : Psalms 107-150 (in Greek, 106-150)
}

The identity and order of the Psalms is the same in Greek as in Hebrew: the difference of numbering is due to psalms being run together or subdivided. There is an apocryphal Psalm 151 added in the Greek, but it is appended at the end, and its title states explicitly that it is 'outside the number'.

The five books are an old division of the collection. This is shown by the fact that, when the Septuagint translation was made, the Psalter was already divided into five books, with all traditions of the text including the doxologies which end the psalms numbered in Hebrew as 41, 72, 89 and 106, at the conclusion of the first four books. The psalm-titles also were already included. The Septuagint translation of the Psalter is usually dated in the early second century $\mathrm{BC}$, and it could be even older, considering how popular the Book of Psalms always was, and how important its place was in worship. The division into five books can hardly, therefore, have been made any later than the third century $\mathrm{BC}$.

Two of the five books are remarkably short. Books III and IV contain only 17 psalms each, whereas Book II contains 31, Book I 41, and Book V 44. This fact, together with the marks that the Psalter contains of an earlier division into three books, suggests that the two short books were probably divided off from other books in order to raise the number from three to five. The motive for doing this is fairly clear. Since the Pentateuch, which contains the law of Tabernacle and Temple worship, is divided into five books, it probably seemed appropriate that the book containing the service of song in the house of the Lord, accompanying that worship, should likewise be divided into five books rather than simply into three. The 
second of the original three books was therefore divided into Books II and III, and the third of the original three books was divided into Books IV and V.

The earlier division of the Psalter into three books (Book I, with 41 psalms; Book II-III, with 48 psalms; Book IV-V, with 61 psalms) is reflected clearly enough in its contents, though confirmed by the psalm-titles. As has often been pointed out, different parts of the Psalter reflect different preferences in the use of the divine name Yahweh (or Jehovah) and the divine title Elohim. In Book I there is a marked preference for the first (used about 275 times, against 48) and again in Books IV-V (used about 329 times, against 47). In Books II-III, however, Elohim is used more frequently than Yahweh (about 248 times, against 70). Especially striking are the cases of psalms repeated (for whatever reason) in different parts of the Psalter. Psalm 14 in Book I is repeated as Psalm 53 in Book IIIII, and Psalm 40:13ff in Book I is repeated as Psalm 70 in Book II-III: the psalms do not recur in precisely identical form, and the balance of the divine names is one of the differences, clearly corresponding to the part of the Psalter in which the respective forms of the psalms occur. ${ }^{2}$ However these different preferences are to be explained, they affect Books II and III as a unity and Books IV and V as a unity, dividing the Psalter into three parts and not five. ${ }^{3}$

Another indication of the original division of the Psalter into three books is the fact that the transition between Book IV and Book V comes in the middle of the Hallelujah psalms (the psalms beginning, ending, or beginning and ending, with Hallelujah). Psalms 104-06 at the end of Book IV are three of these psalms, but the rest are in Book V (Pss. 111$13,115-17,135,146-150)$. The transition comes also in the

2Ps. 57:7-11 and 60:5-12 in Book II-III are likewise repeated as Ps. 108 in Book IV-V, but the divine names are not affected in this case.

${ }^{3}$ The use of the divine names can hardly indicate difference of authorship, as they have often been supposed to do in the Pentateuch, since many psalms use both names. When they do, the prevailing preference of the particular part of the Psalter is usually evident, but it is occasionally reversed. This is the case with Ps. 85 and Pss. $87-89$ in Book II-III, and with Ps. 108 in Book IV-V (on Ps. 108, see previous note). 
middle of the psalms beginning 'O give thanks unto the Lord, for he is good, for his mercy endureth for ever'. Psalm 106 is the first of these, the others being Psalms 107, 118 and 136.

A third indication of the original division of the Psalter into three books is given by the statements about authorship in the psalm-titles, to which we must now turn.

\section{The Titles of the Psalms}

From patristic times, it began to be recognized that the psalmtitles, like the titles of biblical books, are not necessarily to be regarded as part of the text of the psalm (or book), and may well differ from it in authorship and date. They should be treated with respect, because of their antiquity and general acceptation, but not with unquestioning deference. Today, even respect is often denied to them, and they are simply disregarded.

In the Hebrew Psalter, titles precede 116 of the psalms. It is possible that some titles are more properly regarded as subjoined to the previous psalm, but the only clear case of this is the long and complicated title to Psalm 88, the first half of which repeats the title to the previous psalm.

Some titles are much fuller than others, but in their full form they give musical directions (55 psalms), type of composition ( 97 psalms) and authorship (100 psalms), usually in that order, 4 followed in a few cases by a statement about the occasion when the psalm was composed or the occasion or purpose of its use (18 psalms). ${ }^{5}$ The fewness of the statements

4 In the titles of 22 psalms, which are otherwise regular, the authorship is stated before the type of composition: these are Pss. 24, 32, 40, 44-47, $49,56-59,68,77,80,84,85,87,101,109,110,139$. An analysis of the psalm-titles in appended to this article, giving the components in the order followed by the Hebrew Bible. The English order is sometimes different.

${ }^{5}$ The type of composition may itself, sometimes, have implications about the occasion on which, or the purpose for which, the psalm is to be used. For example, the 'Songs of Ascents' (Pss. 120-134) are probably songs of pilgrimage to Mount Zion, and the 'Song of the Dedication of the House' (Ps. 30) could be a psalm composed by David to be used on the occasion described in 1 Ch. 21:28 - 22:1. 
of this fourth kind, and the fact that they always come last, 6 suggest that they may be additions, of later date than the main substance of the titles.

The statements on authorship (which is how they are normally, and with good reason, understood) attribute 73 of the psalms to David, 12 to Asaph, 10 to the sons of Korah, 2 to Solomon, 1 to Heman, 1 to Ethan, 1 to Moses, making 100 in all. Jeduthun is mentioned in three titles, but not as author: two of the psalms in question are said to be by David, the other by Asaph.

When one considers these names, and their distribution in the Psalter, certain facts become clear. David is much the most frequent name, and psalms carrying his name are found in every book of the Psalter-very few in the two short books, it is true, but a substantial number in each of the other three books; and if one divides the Psalter into three, there are 37 in Book I, 19 in Book II-III and 17 in Book IV-V. David's is the only name to occur in Book I, but in the other two sections his name stands alongside others. In Book II-III the other names are those of the Levitical singers. Asaph, Heman, Ethan and the sons of Korah are all known to us in this capacity from the books of Chronicles, Ezra and Nehemiah, and their psalms are all to be found in Book II-III. The only other named psalmist to be found there is Solomon, who could properly be linked with his father David in any of the three parts. The remaining psalmists, most of whom are anonymous, stand alongside David in Book IV-V, though Moses and Solomon also feature there. In Book I there are only four anonymous psalms, and only four in Book II-III, but in Book IV-V there are no less than 42. The Psalter appears, therefore, to have a unity of plan, and to have been organized in three parts on an intelligible principle: Book I consists of Psalms of David, Book II-III consists of Psalms of David and the Levites, and Book IV-V

\footnotetext{
${ }^{6}$ There is one exception. In Ps. 142, the title returns to the type of composition a second time, after its statement about the occasion when the psalm was composed. Three other titles resume the subject of type of composition (Pss. 65, 75, 76) and one title resumes the musical directions (Ps. 46), but not after a reference to the occasion. Ps. 142 seems to be a special case, and is further discussed below.
} 
consists of Psalms of David and the Other Psalmists. The 'Other Psalmists' are mostly anonymous, but they belong to all periods from Moses (Ps. 90) to the Babylonian Exile (Ps. 137). ${ }^{7}$

This then, is a third reason, along with the two given earlier, for believing that the Psalter was originally organized in three books, not five. ${ }^{8}$ The organization was made on a simple, rational principle, and was therefore the work of a single mind. We are not dealing with three different collections, compiled by three different editors, but with a single collection, divided by its editor into three.

\section{The Antiquity of the Psalm-Titles}

But if the psalm-titles imply a division of the Psalter into three books, not five, then the titles must have been added before the division into five books; and even the division into five books, as we have seen, is not more recent than the third century BC. The psalm-titles, therefore, may well be as old as the fourth century BC, and very little (if any) younger than the Books of Chronicles.

There are other indications of their antiquity. When the Septuagint version of the Psalter was made, probably not later than the early second century $\mathrm{BC}$, the psalm-titles were clearly a problem to the translator. He adds to them, sometimes in interesting, sometimes in absurd ways, ${ }^{9}$ but he regularly

\footnotetext{
${ }^{7}$ The reason why there are four anonymous psalms included in each of the other two sections of the Psalter is probably as follows. Ps. 1 is an introduction to the whole Psalter. Ps. 2 is an introduction to the Book of David (Book I), speaking of the theocracy of David and David's son. Ps. 10 is a continuation of Ps. 9. Ps. 33 stands between two psalms of similar theme, and is probably put there for that reason. Ps. 43 is a continuation of Ps. 42. Pss. 66 and 67 are each described as a 'Psalm' and 'a Song', and stand between two compositions of David similarly described. Ps. 71 is a continuation of the theme of Ps. 70.

${ }^{8}$ In the light of the threefold division, the statement in Ps. 72:20 'The prayers of David the son of Jesse are ended' makes better sense. It means that this is the end of a sequence of David's psalms (and one by Solomon) within section 2 .

${ }^{9}$ Interesting additions made by the Septuagint include the assigning of Pss. 24, 48, 93 and 94 to the same days of the week as the Mishash tells
} 
misunderstands and mistranslates the musical directions, which apparently were no longer understood. There are examples of this in the LXX titles to the psalms numbered in Hebrew as 5, 6, 8, 9, 12, 22, 45, 46, 54, 55, 56, 60, 69, 80, 81, 84. Also, the expression 'For the chief musician/choirmaster', which occurs in the titles to 55 psalms, is regularly mistranslated in the Septuagint as 'unto the end'. It might be supposed that this failure to understand was due to geographical and linguistic remoteness rather than lapse of time, but there are two reasons for rejecting this explanation. The first is that the LXX translator was evidently not out of touch with the Temple, since the additions he makes to the titles on liturgical points often reflect Temple practice and are confirmed by the Mishnah (see n. 9). The second reason is that the musical terms were almost as little understood in Semiticspeaking circles as in Hellenistic. The renderings of the psalmtitles made by Aquila are clear evidence of this, for Aquila was rabbinically well-trained. ${ }^{10}$

A third indication of the antiquity of the psalm-titles lies in their community of ideas and expressions with the books of Chronicles, Ezra and Nehemiah. We surveyed earlier the evidence of these books about the psalmody of the sanctuary, some of which corresponds to the text of the Psalter (notably the references to singing and to musical instruments), but much of which corresponds to the psalm-titles. In the historical books we are speaking of, the families of the Levitical singers are led by Asaph, Heman and Ethan (perhaps the same as Jeduthun) and their sons, Heman and his family being sons of Korah; Asaph is the chief of these heads of families, but the master of the song is Chenaniah. Asaph, Heman and Jeduthun and some of their sons have the prophetic gift, and not only play musical instruments but prophesy with them, composing the inspired psalms they sing. The Levites play psalteries set to Alamoth

us were the days on which they were sung in the Temple (Tamid 7:4). Absurd additions include the assigning of Ps. 137 to David, and of Ps. 43 to a different author than Ps. 42.

$10 \mathrm{~A}$ wealth of information on the whole question of the musical directions is to be found in Alfred Sendrey, Music in Ancient Israel (London: Vision Press, 1969). 
and harps set to the Sheminith. All this takes place in David's reign. The sons of Korah are still officiating in the praise of God in the reign of Jehoshaphat. In the reign of Hezekiah, the Levites are singing praises to the Lord with the words of David and of Asaph. At the time of the return from the Exile, Mattaniah the son of Asaph is the chief to begin the thanksgiving in prayer.

In conformity with this, the psalm-titles attribute psalms not only to the authorship of David, but also to that of Asaph, Heman, Ethan and the sons of Korah. ${ }^{11}$ The first three were contemporaries of David, and the sons of Korah, though they continued to sing the psalms in later reigns, are only said to have exercised prophetic gifts in the reign of David. Again, three of the psalm-titles (those of Pss. 39, 62, 77) mention Jeduthun as a leading musical performer of the psalms. Yet again, the 55 psalms with musical directions are all said to be 'For the chief musician/choirmaster'. Only two of these psalms (Pss. 66 and 67) are anonymous: all the rest are by named authors, and all (if we include the sons of Korah) are by authors living in the reign of David. Even the two psalms of Solomon (Pss. 72 and 127) are not said to be for the chief musician/choirmaster. It almost looks, therefore, as if we can give a name to the chief musician/choirmaster. He must be either Chenaniah or Asaph; and he cannot be Asaph, since several of the psalms of Asaph are said to be 'For the chief musician/choirmaster', who can hardly be himself; which means that he is Chenaniah. It would seem, therefore, that the chief musician/choirmaster was not a subsequent collector of psalms, as has often been supposed, but the original performer of them. It may be significant also that virtually all these psalms are in the first three books of the Psalter (the first two main parts of it); in the last main part (Books IV and V) there are only three, Psalms 109, 139 and 140, all attributed to David. Yet the references to the singing of the psalms, and to the use of musical instruments to accompany them, are as numerous in the text of the last part of the Psalter as they are in the text of

${ }^{11}$ The psalms of Asaph are nos 50, 73-83. The psalm of Heman is no 88 . The psalm of Ethan is no 89. The psalms of the sons of Korah are nos $42,44-49,84,85,87$. 
the first two parts put together: 12 it is only that in the psalmtitles musical directions and mention of the chief musician/choirmaster are absent. Many of these other psalms were likewise intended for the Temple, no doubt, which is referred to as frequently as elsewhere in the Psalter, and they would likewise have come into the hands of a chief musician/choirmaster, such as the one to whom Habakkuk's prayer is directed (Hab. 3:19); but because the titles relating to David's reign have a particular chief musician/choirmaster in view, so it seems, the titles of these other psalms (at least in their edited form) abstain from referring to such an officer or from giving him musical directions.

Finally, just as in Chronicles we read of musical instruments set to Alamoth and to the Sheminith for the performance of psalms, the same expressions occur in some of the psalm-titles. The former is found in the title of Psalm 46 (a psalm of the sons of Korah), and the latter in the titles of Psalms 6 and 12 (psalms of David).

It might be argued that this community of ideas and expressions between the psalm-titles and the books of Chronicles, Ezra and Nehemiah is simply due to a literary dependence of the titles upon the books, and does not imply anything about the antiquity of the titles. Such an explanation, however, would be unconvincing. Though there is so much in common, the authors of the psalm-titles have a great deal more technical knowledge than they can have derived from Chronicles, Ezra and Nehemiah. Two of the technical musical expressions, as we have just seen, occur in Chronicles as well, but the psalm-titles contain no less than eleven others (see the titles of Pss. 5, 8, 9, 22, 45, 53, 56-9, 60, 69, 75, 80, 81 and 88). Likewise, the obscure technical names for the different kinds of psalm which are used in the psalm-titles (maskîl, miktām, etc.) cannot have been derived from Chronicles, Ezra or Nehemiah, where they do not occur. If there were dependence on either

12There are 36 references to singing in Books I-III of the Psalter, and the same number in Books IV-V. Musical instruments are referred to nine times in Books I-III (four or five different instruments being mentioned) and ten times in Books IV-V (five or six different instruments being mentioned). 
side, therefore, one would have to say that the psalm-titles were the source, but in fact there is not much indication of dependence, simply of a community of ideas and expressions, which is mutually corroborating, and which goes back to a single historical period of considerable antiquity.

To say that the psalm-titles and Chronicles, Ezra and Nehemiah go back to a single historical period could mean either of two things. It could mean the short period, leading up to about $400 \mathrm{BC}$, within which the three works were written, or it could mean the much longer period, beginning much earlier, during which the events they record took place. We have already suggested that the Chronicler perhaps deserves more credit as a historian than he usually receives, and certainly if what he says about his sources is true: is there any adequate reason why all that he does not have in common with Samuel and Kings should be attributed to his own ideas and contemporary experience, and not in some measure to the fuller form of the annals of his country, with their prophetic authors still distinguishable, to which he ascribes the authority for what he says? ${ }^{13}$ In particular, we have suggested that what he says about the origin of the service of song in the sanctuary is probable rather than improbable. So it should not be assumed without discussion that the common period reflected by the psalm-titles and Chronicles is post-exilic rather than pre-exilic.

We must now come back to the striking fact that the meaning of the musical directions in the psalm-titles was forgotten. Since the psalms were being musically performed by the Levites in the Temple continuously, it is difficult to see how this could have happened. Yet it had already happened by the

${ }^{13}$ The Chronicler refers to a multitude of prophetic sources ( $1 \mathrm{Ch} .29: 29$; 2 Ch. $9: 29 ; 12: 15 ; 13: 22 ; 20: 34 ; 26: 22 ; 32: 32 ; 33: 18-19)$ and to the Book of the Kings of Israel and Judah (1 Ch. 9:1; 2 Ch. 16:11; 24:27; 25:26; 27:7; 28:26; $35: 27 ; 36: 8)$ which apparently incorporated some at least of the prophetic sources he mentions ( $2 \mathrm{Ch}$. 20:34; 32:32). The Books of Kings also refer to sources, namely, the Book of the Acts of Solomon, the Book of the Chronicles of the Kings of Israel and the Book of the Chronicles of the Kings of Judah, and the latter two of these sources, in combined form, may have made up the Book of the Kings of Israel and Judah used by the Chronicler. 
time the Septuagint translation of the Psalms (with their titles) was made, i.e., by the early-second century BC. It took place in Semitic circles as well as Hellenistic, for the rabbis had no traditional knowledge on the subject, as they had on many Temple matters, ${ }^{14}$ and Aquila is as ignorant about it as the Septuagint before him or the Midrash on Psalms after him. If the psalm-titles belonged to the period of the writing of Chronicles, about $400 \mathrm{BC}$ or soon after, and reflected Temple practice of that period (the practice also reflected in Ezra and Nehemiah), then this practice must have ceased almost immediately afterwards, in order to leave time for it to have been forgotten by the time the Septuagint translation of Psalms was made, about 200 years later. Why should it have ceased? Was the Temple at the mercy of revolutionary musical fashions? Or did the difficulties of the Levites, which Nehemiah attempted to remedy (Ne. 13:10-14), and which later recurred, lead to them totally forsaking the Temple and to their singers forgetting their art? We know that the duties and rights of the Levites were to some extent taken over by the priesthood, so much so that, according to the Mishnah, John Hyrcanus about the beginning of the first century BC abolished the avowal of Deuteronomy 26:13 (Maaser Sheni 5:15; Sotah 9:10). Nevertheless, those of the Levites who were singers continued to perform the Psalms in the Temple right up to its destruction in $\mathrm{AD} 70$, as both Josephus and the Mishnah bear witness, 15 and before then we do not know that their activities were ever completely interrupted, except during the three-year desecration of the Temple in the mid-second century BC by Antiochus Epiphanes. This was much too short a period to account for them forgetting their music, and was also too late.

However, there was a time when the Temple was in ruins for more than two generations; when the Israelites hung up their harps because they felt that they could not sing the Lord's song in a strange land; and when they forgot even how to speak their native language. This time was, of course, the

\footnotetext{
${ }^{14}$ See, for examples of this knowledge, the tractates Tamid and Middoth in the Mishnah.

15Josephus, Antiquities 20:9:6, or 20:216-18; Mishnah, Sukkah 5:4; Arakhin 2:6; Tamid 7:3f; Middoth 2:5f.
} 
Babylonian Exile. If the Levites forgot their music during that period, one could well understand it. But what this would mean is that the musical directions of the psalm-titles are (as indeed they profess to be) pre-exilic. ${ }^{16}$ It would also mean that the more general community of ideas and expressions reflected in the psalm-titles and in Chronicles, though to some extent continued in Ezra and Nehemiah, belongs essentially to the pre-exilic period-to the period of which Chronicles speaks, rather than the period in which it was written. The obscurity of the names for different types of psalm in the psalm-titles would also be explained by a pre-exilic date, for these technicalities also could have been forgotten during the Exile. And what about the statements on authorship? If the psalm-titles are essentially pre-exilic, the statements they make on the authorship of the psalms (which are among the three regular components of the titles, reflect the ancient division of the Psalter into three, and are part of the general community of ideas between the titles and Chronicles) have to be taken very seriously. In the Septuagint, many of the anonymous psalms are given titles attributing them to David, sometimes in absurd cases (see n. 9); an apocryphal psalm is also attributed to David; and the latter practice is likewise found at Qumran. But where any canonical psalm carries an ancient Hebrew attribution, this needs to be treated with much greater respect. Even if it may not always be correct, the presumption should be that it is.

This, of course, is quite contrary to the received wisdom. The Psalter has usually been held to be late, because it belongs to the latest section of the canon, the Hagiographa, and the psalm-titles have usually been dismissed, as of no historical value. Since it can be shown, however, that the third section of the canon was probably compiled at the same time as

${ }^{16}$ Compare the obscure musical term, related to that in the title of Ps. 7, used in the title of the prayer of Habakkuk (Hab. 3:1), which is attributed to a prophet of the late monarchy. Here both the title and the final note (Hab. 3:19) are similar to psalm-titles, though not quite the same, and Habakkuk's use of the musical interlude called 'Selah' (Hab. $3: 3,9,13)$ imitates Davidic usage. 
the second, and not at any subsequent period, 17 and since we now have the Qumran Book of Hymns to compare the Psalter with, in point of antiquity, 18 it is time for these assumptions to be revised. Once they have been revised, and the early origin of the Psalter has been recognized, it becomes possible to take the psalm-titles more seriously, as we are here trying to do.

\section{The Final Component of the Psalm-Titles}

It was noted earlier that the normal components of a psalmtitle are up to three in number: musical directions (55 psalms), type of composition (97 psalms) and authorship (100 psalms), usually in that order. These are followed in a few cases by a statement about the occasion when the psalm was composed or the occasion or purpose of its use (18 psalms). It was further remarked that the fewness of the statements of this fourth kind, and the fact that they always come last, suggest that they may be additions, of later date than the main substance of the titles. Where the occasion of composition is given, which happens in 13 cases, the psalm is always one bearing the name of David (Pss. 3, 7, 18, 34, 51, 52, 54, 56, 57, 59, 60, 63, 142), and it has been plausibly proposed by Brevard Childs that the suggested occasion has been prompted by exegesis, comparing the narrative of Samuel or Chronicles with the sentiments expressed in the psalm; and identifying occasions in the earlier or later life of David when the sentiments would have been appropriate. ${ }^{19}$ Where the statement concerns the use of the psalm, which happens in six cases (Pss. 38, 60, 70, 92, 100, 102), this also may be due to exegesis-exegesis of the psalm itself.

${ }^{17}$ See my book The Old Testament Canon of the New Testament Church, and its Background in Early Judaism (London: SPCK, 1985), especially Ch 4, 'The Structure of the Canon'.

$18 \mathrm{M}$.J. Dahood properly points out that the Hebrew Psalter must be separated by a long lapse of time from the LXX translation and from the Qumran Cave 1 Book of Hymns (Psalms [Anchor Bible; New York: Doubleday, 1966-70] Vol. I, xxix-xxx; Vol. III, xxxiv-xxxvii). The Book of Hymns probably belongs to the first or second century $\mathrm{BC}$.

${ }^{19}$ B.S. Childs, 'Psalm Titles and Midrashic Exegesis', JSS 16 (1971) 137150. 
'To bring to remembrance' (viz. before God) expresses the natural sense of Psalms 38 and 70, 'for thanksgiving' expresses the natural sense of Psalm 100, and 'A prayer of the afflicted, when he is overwhelmed, and pours out his complaint before the Lord' expresses the natural sense of Psalm 102. 'To teach' (viz. trust in the Lord) is a possible interpretation of Psalm 60. It is often thought that there are liturgical overtones also, which would in some cases be a natural consequence (e.g., using Ps. 100 , as a psalm of thanksgiving, at the thank-offering), but the only psalm where the fact is explicit is Psalm 92, 'for the sabbath day'. Even this phrase may be due to exegesis-that the psalm was thought suitable for the sabbath day, rather than that it was composed for the sabbath day. Certainly the other psalms for the days of the week were applied to this use rather than composed for it, and one of the mysteries of liturgical history is why the seven psalms were thought particularly suitable for the purpose-Psalm 92 being no exception.

That these final components of the psalm-titles tend to be later additions can in some cases be shown to be very probable because of the nature of the exegesis involved. One of the curiosities of rabbinical interpretation of the Bible is what has been called 'homiletic identification'. There is an explanation of this phenomenon in chapter 21 of Z.H. Chajes's book, known in English as The Student's Guide through the Talmud. 20 The rabbis were accustomed, for homiletic purposes, to identify as one and the same Old Testament characters who were historically distinct, and sometimes of quite different generations, but who were linked by similarity of name or other characteristics. There are examples in the Mishnah, 2 Esdras and possibly the New Testament, ${ }^{21}$ but the earliest clear instance is in the title of Psalm 34, where Achish, the Philistine king with whom David sojourned (1 Sa. 21:10-22:1), is called Abimelech, i.e., the Philistine king, or kings, with whom Abraham and Isaac sojourned (Gn. 20-21, 26). The Midrash on Psalms recognizes that this is a homiletic identification, which

${ }^{20}$ London: East and West Library, 1952.

${ }^{21}$ See my book The Old Testament Canon of the New Testament Church, 217-222. 
is much more plausible than to think it a mistake; but, though it is the earliest example, predating the Septuagint translation, it would be hazardous to date the convention too early. It presumably belongs to the last few centuries BC. So the final component of the psalm-titles should probably be dated in that period.

There are other likely examples of the same phenomenon elsewhere in the psalm-titles. The mysterious 'Cush, a Benjamite' in the title of Psalm 7, who has so puzzled commentators, is probably a play on the name of Kish the father of Saul, and refers to Shimei, the Benjamite who cursed David when he was fleeing from Absalom his son (2 Sa. 16:514). These were the 'words' which are said to have provoked the psalm. Shimei is described in 2 Samuel as 'the son of Gera' (a remote ancestor), but his relationship to Kish is inferred from the genealogy of Mordecai, another Benjamite, in Esther 2:5, where Mordecai is described as 'the son of Jair, the son of Shimei, the son of Kish'. Shimei, then, is here called by the name of his father Kish, and Kish is identified with the similar Cush for derogatory reasons, Cush being a son of Ham and the father of Nimrod, king of Babel and builder of Niniveh (Gn. 10:6-12).

The final examples could easily be overlooked. In the titles of Psalms 88 and 89, Heman and Ethan, the Levitical authors, have had the patronym 'the Ezrahite' appended to their names. Now, Ethan the Ezrahite and his relative Heman were two of the wise men of the age of Solomon, mentioned in 1 Kings 4:31. However, we know from 1 Chronicles 2:6 that they belonged to the tribe of Judah, and were therefore historically quite distinct from Heman and Ethan the Levitical singers, who nevertheless are here identified with them, so that they too may be thought of as wise.

Having said all this, there are one or two instances in which the final component of the psalm-title would seem to be older. In Psalm 18, it corresponds to the words introducing the text of the psalm in 2 Samuel 22, where the same psalm also occurs. Again, in Psalm 142, as was noted above, the statement of the occasion is not in fact the final component of the title, so may be an original part of it. In these two instances, therefore, 
the statement of the occasion may be particularly ancient, and due to historical tradition rather than to exegesis; nor can one have much confidence in limiting the instances to a bare two.22 However, when historical tradition had made its contribution, exegesis evidently took over, and amplified a number of other titles in a similar fashion.

\section{A Divergent View}

Before concluding, we must look seriously at some Qumran evidence which has been interpreted in a very different way. J.A. Sanders, who edited The Psalms Scroll of Qumran Cave 11 $\left(11 Q P s^{a}\right)$ as volume 4 of Discoveries in the Judaean Desert of Jordan, ${ }^{23}$ propounded the hypothesis that this scroll shows the contents and arrangement of the Psalter to have been extremely fluid as late as the first century $\mathrm{AD}$, when the scroll was written. His hypothesis has since been defended by G.H. Wilson in his elaborate and informative book The Editing of the Hebrew Psalter, ${ }^{24}$ and especially in chapters 4 and 5. Various scholars have contested the hypothesis, notably P.W. Skehan, arguing that the Cave 11 Psalter does not contain a different tradition of the scriptural text, but has simply been adapted for liturgical purposes. 25

Thirty or more distinct fragmentary manuscripts of the Book of Psalms were found at Qumran. Of these, seven in all show definite or probable peculiarities of order, content or

${ }^{22}$ As J.A. Motyer remarks, it is a mistake to overlook the nature of the psalms, as meditations, not descriptions. 'In each instance a satisfying case can be made out that either within the incident mentioned or in subsequent reflection David could well have voiced these sentiments' (New Bible Commentary, 485-6). F.D. Kidner's fuller discussion, 'Davidic Episodes in the Headings', reaches similar conclusions: see his Psalms 1-72 (Leicester: IVP, 1973) 43-46. Consider also what is said in note 5 above.

23Oxford: Clarendon, 1965.

24SBL Dissertation Series 76; Chico: Scholars Press, 1985.

${ }^{25}$ See especially his essay 'Qumran and Old Testament Criticism', in M. Delcor (ed.) Qumran: sa piété, sa théologie et son milieu (Bibliotheca Ephemeridum Theologicarum Lovaniensium 46; Paris: Duculot, 1978), 163-182. 
both, the Cave 11 scroll being much the largest example. Some manuscripts are too fragmentary to allow one to draw conclusions, but, where conclusions are possible, the irregular manuscripts are always in a minority. On the other hand, they belong to various periods, and the oldest datable manuscripts (2nd century BC onwards) are irregular. Wilson argues, following Sanders, that the manuscripts indicate a progressive stabilization of the text of the Psalter, over the course of time, starting at the beginning of the Psalter and finishing at the end, which might suggest that the sections of the Psalter were compiled at different periods, and that the older sections were stabilized first.

However, what is presumably meant is that there was a progressive stabilization of the text at Qumran, since the Septuagint shows that it was already very stable elsewhere. Yet even at Qumran, this conclusion is hard to accept, first, because the number of significant examples is scarcely enough to be statistically reliable (only three manuscripts, in total, speak for Book II of the Psalter, and only three for Book III; and even for Book I there are still two irregular manuscripts, the same as for Book IV);26 secondly, because the abundance of evidence for irregularities in Books IV-V corresponds directly to the abundance of manuscript material for those two books;27 and thirdly, because the irregular manuscripts, regardless of their date, are often so very irregular, drawing together psalms from Books I and II (4QPsa), books I and V (4QPs $)^{2}$, books I, III, IV and V (4QPse), and not simply from books IV and $\mathrm{V}$, to say nothing of the apocryphal compositions included.28

The ten or so apocryphal compositions can hardly have been composed at Qumran, since they include Psalm 151 of the Septuagint, in Hebrew, and Ecclesiasticus 51:13-30; but the latter example in particular (a very personal hymn by Ben Sira) shows that it would be rash to date these compositions early. Scribes who insert in a biblical manuscript an excerpt of this

${ }^{26}$ See Wilson, Editing, 120-21.

27Especially in the large Cave 11 scroll, which extends only to those two books.

${ }^{28}$ The three scrolls named are dated mid 2nd century BC, c. $50 \mathrm{BC}$, and first half of 1st century AD, respectively (see Wilson, Editing, 122). 
kind from a recent book are not intending to transmit any traditional form of the biblical text, and the hypothesis that they are compiling a liturgical manual, partly out of biblical and partly out of non-biblical materials, would have much more to be said for it.

One of Skehan's most potent arguments in favour of the liturgical hypothesis is that even the irregular manuscripts reflect a knowledge of the regular Psalter. In the great Cave 11 scroll, there is a prose note giving an idealized account of David's compositions, and stating that he wrote 3,600 psalms and 450 songs. Now, 450 is three times 150 , and 3,600 is 150 multiplied by 24 , the number of the courses of the Levites appointed to sing the psalms in the Temple (1 Ch. 25). This is clear evidence that 150, and not a larger figure, was known and accepted at Qumran as the number of the psalms. There is other evidence to the same effect. As Wilson shows, the psalmtitles were known at Qumran in more or less their Massoretic form;29 and we have seen that the psalm-titles divide the Psalter into its three original sections, Book I, Book II-III and Book IV-V. Also, Wilson tells us that in one of the irregular manuscripts there is a fragment of Psalm 89:52, i.e., of the doxology ending Book III. ${ }^{30}$ Thus, the eccentric manuscripts reflect another count and another arrangement of the psalms, older than their own. Why, then, do they substitute a fresh one? Very likely for liturgical reasons. 31

${ }^{29}$ Wilson, Editing, appendix A.

30Wilson, Editing, 232.

${ }^{31}$ Assuming that the irregular manuscripts are, after all, liturgical adaptations of the regular Psalter, various interpretations of their liturgical use are possible. For an attempt at a comprehensive hypothesis, see my article 'The Courses of the Levites and the Eccentric Psalms Scrolls from Qumran', in Revue de Qumran Vol. XI, no. 44 (December 1984). 


\section{The Early History Reconstructed}

The thesis which this study has argued is that the Psalms are old, and that the Psalter is a relatively old collection of them. ${ }^{32}$ Many of them, probably, were written by David and his contemporaries, and none of them need be of later date than the return from the Exile. The collection still bears clear marks of having originally been organized in three parts, and this was the work of an editor in the period of the monarchy, when the musical directions and the technical terms for different kinds of psalm were still understood, and the traditional authorship of many of the psalms was still remembered. The substance of the psalm-titles dates from this period, and the musical directions, addressed to the chief musician/choirmaster, may have originated as the suggestions made to that officer, in Davidic times, by the psalmists themselves.

The editor who compiled the Psalter in three parts is perhaps responsible for the Elohistic preference of the second part; one may suggest that, having noted this preference in the Levitical psalmists, he extended it to the Davidic material in the same part also. He may likewise have been responsible for assigning the (mostly anonymous) Songs of Ascents, as a body, to the third part, the (wholly anonymous) Hallelujah and 'the LORD reigneth' psalms, in a more dispersed way, to the same part, and the (partly Davidic, partly anonymous) abecedarian psalms, in equal shares, to the first part and the third. ${ }^{33}$ Whether the editor was a selector as well as a collector, and how far he had pre-existing collections to work from, we do not know.

After the Exile, probably, when the Temple had been restored and the Pentateuch had been established by Ezra more

\footnotetext{
${ }^{32}$ How different and how uncertain the history of the Psalter seems on the opposite assumption of late dates may be seen from J. Clinton McCann's recent symposium The Shape and Shaping of the Psalter (JSOTS 159; Sheffield: JSOT Press, 1993).

33The abecedarian psalms are the eight arranged according to the letters of the Hebrew alphabet. Four of them, all Davidic (Pss. 9-10, 25, 34, 37), are in the first book, and the other four, three anonymous and one Davidic (Pss. 111, 112, 119, 145), are in the fifth book. The psalms beginning 'The LORD reigneth' are Pss. 93, 97 and 99 (cp. also Ps. 96:10).
} 
firmly than ever before as the basis of Israel's life and worship, two of the three parts of the Psalter were subdivided, so that the service of song, like the manual of the sacrificial worship which it accompanied, should be in five books. It may have been on the same occasion that Psalm 137, and any other psalm dating from the Exile or the Return, were added to the collection. Finally, but still before the translation of the Psalter into Greek, the supplements which conclude some of the psalm-titles, and which reflect the early stages of rabbinical exegesis, were appended, being suggested by what a few of the psalm-titles already contained. With these additions made, the Psalter had reached the form which is now familiar to us in the Hebrew Bible. 


\section{ANALYSIS OF THE PSALM TITLES}

\begin{tabular}{|c|c|c|c|c|c|}
\hline \multicolumn{6}{|c|}{ (For a key to abbreviations, see page 27 below) } \\
\hline $\begin{array}{l}\text { Psalm } \\
\text { no. }\end{array}$ & $\begin{array}{l}\text { Musical } \\
\text { Directions }\end{array}$ & $\begin{array}{l}\text { Type } \\
\text { (or Author) }\end{array}$ & $\begin{array}{l}\text { Author } \\
\text { (or Type) }\end{array}$ & $\begin{array}{l}\text { Occasion } \\
\text { or Use }\end{array}$ & LXX Deviations \\
\hline 3 & & Type & Author (D) & Occasion & \\
\hline 4 & Yes & Type & Author (D) & & \\
\hline 5 & Yes & Type & Author (D) & & misunderstands \\
\hline 6 & Yes & Type & Author (D) & & misunderstands \\
\hline 7 & & Type & Author (D) & Occasion & \\
\hline 8 & Yes & Type & Author (D) & & misunderstands \\
\hline 9 & Yes & Type & Author (D) & & misunderstands \\
\hline 11 & Yes & & Author (D) & & \\
\hline 12 & Yes & Type & Author (D) & & misunderstands \\
\hline 13 & Yes & Type & Author (D) & & \\
\hline 14 & Yes & & Author (D) & & \\
\hline 15 & & Type & Author (D) & & \\
\hline 16 & & Type & Author (D) & & \\
\hline 17 & & Type & Author (D) & & \\
\hline 18 & Yes & & Author (D) & Occasion & \\
\hline 19 & Yes & Type & Author (D) & & \\
\hline 20 & Yes & Type & Author (D) & & \\
\hline 21 & Yes & Type & Author (D) & & \\
\hline 22 & Yes & Type & Author (D) & & misunderstands \\
\hline 23 & & Type & Author (D) & & \\
\hline 24 & & Author (D) & Type & & adds use \\
\hline 25 & & & Author (D) & & \\
\hline 26 & & & Author (D) & & \\
\hline 27 & & & Author (D) & & adds occasion \\
\hline 28 & & & Author (D) & & \\
\hline 29 & & Type & Author (D) & & adds use \\
\hline 30 & & Type & Author (D) & & \\
\hline 31 & Yes & Type & Author (D) & & adds occasion \\
\hline 32 & & Author (D) & Type & & adds author to 33 \\
\hline 34 & & & Author (D) & Occasion & \\
\hline 35 & & & Author (D) & & \\
\hline 36 & Yes & & Author (D) & & \\
\hline 37 & & & Author (D) & & \\
\hline 38 & & Type & Author (D) & Use & amplifies use \\
\hline 39 & Yes & Type & Author (D) & & \\
\hline 40 & Yes & Author (D) & Type & & \\
\hline 41 & Yes & Type & Author (D) & & \\
\hline 42 & Yes & Type & Author (K) & & adds type and \\
\hline 44 & Yes & Author (K) & Type & & author to 43 \\
\hline 45 & Yes & Author (K) & Type & & misunderstands \\
\hline 46 & Yes $(\gg>)$ & Author (K) & Type & & misunderstands \\
\hline 47 & Yes & Author (K) & Type & & \\
\hline 48 & & Type & Author (K) & & adds use \\
\hline 49 & Yes & Author (K) & Type & & \\
\hline 50 & & Type & Author (A) & & \\
\hline 51 & Yes & Type & Author (D) & Occasion & \\
\hline 52 & Yes & Type & Author (D) & Occasion & \\
\hline 53 & Yes & Type & Author (D) & & \\
\hline
\end{tabular}




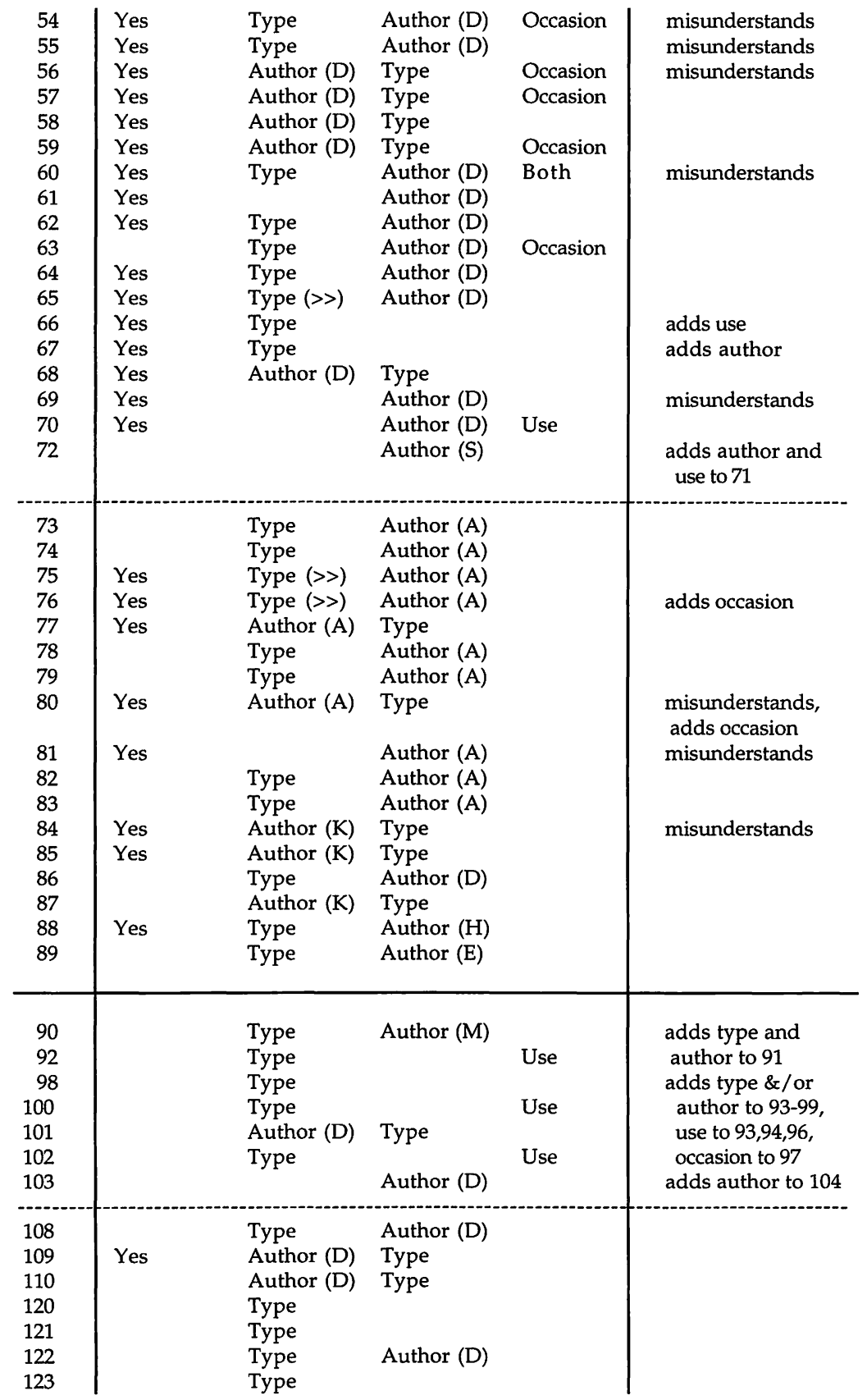


BECKWITH: The Early History of the Psalter

\begin{tabular}{|c|c|c|c|c|c|}
\hline 124 & & Type & Author (D) & & \\
\hline 125 & & Type & & & \\
\hline 126 & & Type & & & \\
\hline 127 & & Type & Author (S) & & omits author \\
\hline 128 & & Type & & & \\
\hline 129 & & Type & & & \\
\hline 130 & & Type & & & \\
\hline 131 & & Type & Author (D) & & \\
\hline 132 & & Type & & & \\
\hline 133 & & Type & Author (D) & & \\
\hline 134 & & Type & & & \\
\hline 138 & & & Author (D) & & adds author to 137 \\
\hline 139 & Yes & Author (D) & Type & & \\
\hline 140 & Yes & Type & Author (D) & & \\
\hline 141 & & Type & Author (D) & & \\
\hline 142 & & Type $(>>)$ & Author (D) & Occasion & \\
\hline 143 & & Type & Author (D) & & adds occasion \\
\hline 144 & & & Author (D) & & adds occasion \\
\hline 145 & & Type & Author (D) & & $\begin{array}{l}\text { adds author (?) to } \\
146-148\end{array}$ \\
\hline
\end{tabular}

KEY

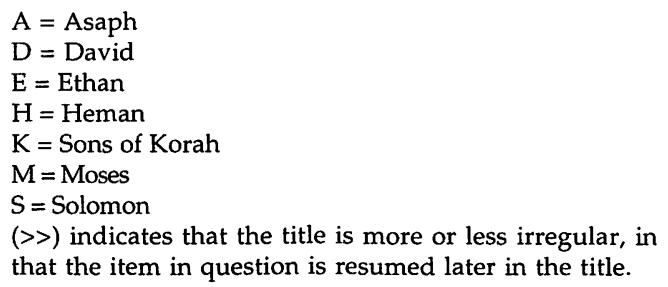

